\title{
Socio Economic Impact of Mission Mangalam yojana on Rural Women
}

\author{
Nirali Ben Baria ${ }^{1 *}$, O.P. Sharma ${ }^{2}$ and Munni Kumari ${ }^{3}$ \\ ${ }^{1}$ Behind Govt. hospital, Fatepura, Dahod-389151, India \\ ${ }^{2}$ Department of Extension Education, NMCA, NAU, Navsari, India \\ ${ }^{3}$ Ward no.-08, Raniganj, Meriganj, Ataria, Bihar-854334, India \\ *Corresponding author
}

\section{A B S T R A C T}

Rural women are the vulnerable and underprivileged class of the society

\section{Keywords}

Socio-economic impact, Rural women, Mission Mangalam yojana

Article Info

Accepted:

04 January 2018

Available Online:

10 February 2018 and are also amongst the poorest, they face physical and psychological violence in different areas of world. Thus, helping them should be a priority. For all these reasons, it is important to strengthen the women socially and economically. Provision of employment opportunities and income for rural women is one of the ways to improve their socio economic status. Considering the importance of socio-economic status in women empowerment; a study entitled; "Socio-Economic impact of Mission Mangalam Yojana" was conducted with 100 rural women in Navsari district of Gujarat State. The findings of study revealed that Majority of rural women have been vastly benefitted through MMY and the scheme made a remarkable change in the socio-economic status of selected respondent rural women.

\section{Introduction}

The investment in women empowerment will lead to greater contribution of women in the growth and development of the economy. Due to the effort of government and nongovernment agencies in the world, there is very good progress in different areas of women but still women face many hurdles to economic, social and political opportunities. They are not treated as equal to men in terms of rights of inheritance, property rights, and rights to acquire nationality, seek employment and laws related to marriage and divorce. For all these reasons, it is important to provide credit to the women than men. The credit can be a powerful tool for poor women to turn out to be better fighters. On the occasion of the Golden Jubilee Year celebration of Gujarat State starting from $1^{\text {st }}$ May 2010, the government of Gujarat launched an ambitious campaign to organize the poor into Self Help Groups/ other organizations of the poor, link them with banks build capacities in them and lead them towards sustainable livelihoods by the name Mission Mangalam. Mission 
Mangalam, through its multi-dimensional policies and interventions aims to provide permanent solutions. It strives to provide options of income generating opportunities, ready to access means of production, affordable basic services and protection of law. Thus, 'Mission Mangalam' is a complete package with all these elements incorporated in it.

Considering this, the present study was undertaken with a specific objective, Socio Economic Impact of Mission Mangalam Yojana on Rural Women in Navsari district of Gujarat state.

\section{Materials and Methods}

The study was conducted during June 2017 in Navsari district of Gujarat state. The District comprises of six Talukas, among which Chikhli and Jalalpore talukas were randomly selected for the study. From each taluka five villages were selected randomly. Then from each of the selected village 10 rural women were selected considering their mandatory membership in MMY. Thus, 100 respondents were selected as a sample size for the study. Data were collected with the help of personal interview method. Frequency and percentage were used for analysis of the data.

\section{Results and Discussion}

Scale used by S. K. Mehta (2011) was used as such for analyzing socio economic impact; categorization of indicators also done accordingly. From before and after prevailing situations, change was measured which was considered as socio economic impact of Mission Mangalam yojana on the respondent rural women.

The data presented in table 1 revealed that there has been 36.00 per cent increase in MMY respondents, who can now freely talk in the meetings while there has been a decrease by 18.00 per cent and 18.00 per cent respondents, who sometimes talks or hesitates to talk respectively.

It can be seen that there has been an increase by 36.00 per cent in MMY respondents with respect to confidence building factors.

In frequency of interaction with outsiders it was observed that in pre MMY period there has been 41.00 per cent of the respondents were not interacted with officials whereas after associating with MMY 91.00 per cent members had interacted with the outsiders. Changed observed in their status of amenities was of 31.00 per cent.

Further it was found that there has been almost 51.00 and 45.00 per cent increase in respondents, who were saving their money in bank and MMY and there have been 35.00, 14.00 and 04.00 per cent increase in respondents from pre MMY, who had taken loan between Rs. 5000, Rs. 5000-10000, Rs. 15000- 20000 in the post MMY respectively.

Table.1 Socio Economic Impact of Mission Mangalam yojana on rural women $(n=100)$

\begin{tabular}{|c|c|c|c|c|c|c|c|}
\hline Sr. & \multirow[t]{2}{*}{ Indicators } & \multicolumn{2}{|c|}{ PRE - MMY } & \multicolumn{2}{|c|}{ POST - MMY } & \multicolumn{2}{|c|}{ CHANGE } \\
\hline No. & & $\mathbf{F}$ & $\%$ & $\mathbf{F}$ & $\%$ & $\mathbf{F}$ & $\%$ \\
\hline $\mathbf{A}$ & Communication level & & & & & & \\
\hline 1 & Free Talks & 33 & 33 & 69 & 69 & 36 & 36 \\
\hline 2 & Sometimes Talks & 42 & 42 & 24 & 24 & 18 & 18 \\
\hline 3 & Hesitates to Talk & 25 & 25 & 07 & 07 & 18 & 18 \\
\hline
\end{tabular}




\begin{tabular}{|c|c|c|c|c|c|c|c|}
\hline B & Self confidence & & & & & & \\
\hline 1 & Members Revealed Confidence & 12 & 12 & 35 & 35 & 23 & 23 \\
\hline 2 & Status in Family & 44 & 44 & 52 & 52 & 8 & 8 \\
\hline 3 & Helpsin Family Finance & 38 & 38 & 53 & 53 & 15 & 15 \\
\hline 4 & More Respectful & 28 & 28 & 73 & 73 & 45 & 45 \\
\hline 5 & Help to Others & 20 & 20 & 58 & 58 & 38 & 38 \\
\hline $\mathrm{C}$ & Frequency of interaction with others & & & & & & \\
\hline 1 & None & 45 & 45 & 9 & 9 & 36 & 36 \\
\hline 2 & Once & 27 & 27 & 17 & 17 & 10 & 10 \\
\hline 3 & 2-4 times & 19 & 19 & 23 & 23 & 4 & 4 \\
\hline 4 & More than 4 times & 9 & 9 & 51 & 51 & 42 & 42 \\
\hline D & s4) Status of Access to Amenities & & & & & & \\
\hline 1 & Medical Facilities & 42 & 42 & 46 & 46 & 4 & 4 \\
\hline 2 & Sanitation Facilities & 49 & 49 & 53 & 53 & 4 & 4 \\
\hline 3 & Water Supply Facilities & 32 & 32 & 40 & 40 & 8 & 8 \\
\hline 4 & Market Facilities & 52 & 52 & 59 & 59 & 7 & 7 \\
\hline 5 & Adequate Transport Facilities & 43 & 43 & 53 & 53 & 10 & 10 \\
\hline 6 & School For Children & 42 & 42 & 42 & 42 & 0 & 0 \\
\hline $\mathbf{E}$ & Change in the saving pattern & & & & & & \\
\hline 1 & In Bank \& Post Office & 6 & 6 & 57 & 57 & 51 & 51 \\
\hline 2 & In MMY & 0 & 0 & 45 & 45 & 45 & 45 \\
\hline 3 & Cash in Hand & 78 & 78 & 10 & 10 & 68 & 68 \\
\hline 4 & Loan to relatives & 16 & 16 & 2 & 2 & 14 & 14 \\
\hline $\mathbf{F}$ & $\begin{array}{l}\text { Change in the cumulative saving } \\
\text { pattern }\end{array}$ & & & & & & \\
\hline 1 & Rs. $0-500$ & 56 & 56 & 8 & 8 & 48 & 48 \\
\hline 2 & Rs. $500-1000$ & 23 & 23 & 11 & 11 & 12 & 12 \\
\hline 3 & Rs. $1000-1500$ & 17 & 17 & 17 & 17 & 0 & 0 \\
\hline 4 & Rs. $1500-2000$ & 4 & 4 & 29 & 29 & 25 & 25 \\
\hline 5 & More than Rs. 2000 & 0 & 0 & 33 & 33 & 33 & 33 \\
\hline $\mathbf{G}$ & Size of loan taken & & & & & & \\
\hline 1 & Nil & 77 & 77 & 29 & 29 & 18 & 18 \\
\hline 2 & Less than Rs. 5000 & 2 & 2 & 37 & 37 & 35 & 35 \\
\hline 3 & Rs.5001-10000 & 1 & 1 & 15 & 15 & 14 & 14 \\
\hline 4 & Rs. $10001-15000$ & 7 & 7 & 7 & 7 & 0 & 0 \\
\hline 5 & Rs. $15001-20000$ & 13 & 13 & 9 & 9 & 4 & 4 \\
\hline 6 & Rs. $20001-25000$ & 0 & 0 & 3 & 3 & 3 & 3 \\
\hline 7 & More than Rs. 25000 & 0 & 0 & 0 & 0 & 0 & 0 \\
\hline
\end{tabular}


It can be concluded that Mission Mangalam yojana exert a good impact on respondents, in their ability to express their feelings and has made rural women more confident to express themselves, Majority of the respondents showing positive responses to the questions about self-confidence. In respect of status of access to amenities it was observed that after joining the MMY the members have improved in getting access to amenities like medical, sanitation, education, market, water supply, transport. Majority of respondents have started taking loan from MMY in order to run their day to day consumption expenses.

\section{References}

Mehta, S.K., Mishra, H.G. and Singh, A. 2011. Role of self-help groups in socio economic change of vulnerable poor of Jammu region. International conference on Economics and finance research, 4.

\section{How to cite this article:}

Nirali Ben Baria, O.P. Sharma and Munni Kumari. 2018. Socio Economic Impact of Mission Mangalam yojana on Rural Women. Int.J.Curr.Microbiol.App.Sci. 7(02): 216-219. doi: https://doi.org/10.20546/ijcmas.2018.702.027 